\title{
A Study on Antitubercular and Antimicrobial Activity of Isoniazid Derivative
}

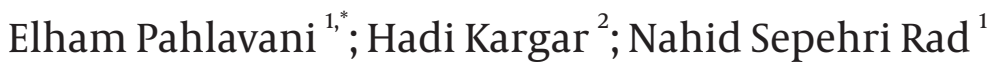 \\ ${ }^{1}$ Infectious Diseases and Tropical Medicine Research Center, Zahedan University of Medical Sciences, Zahedan, IR Iran \\ ${ }^{2}$ Department of Chemistry, Payame Noor University, Tehran, IR Iran \\ ${ }^{*}$ Corresponding author: Elham Pahlavani, Infectious Diseases and Tropical Medicine Research Center, Zahedan University of Medical Sciences, Zahedan, IR Iran, \\ E-mail: elham_pahlavani@yahoo.com
}

Received:January 20, 2014; Accepted: February 25, 2014

\begin{abstract}
Background: Hydrazones belonging to azomethine class of compounds have attracted the attention of many chemists owing to their wide spectrum of pharmacological activity profile with structural flexibility and ligating behavior.

Objectives: We aimed to synthesize a potential ligand containing both, isonicotinoylhydrazide and 3-ethoxy-2-hydroxybenzilidine moieties, linked through azomethine group.

Materials and Methods: In this descriptive study, a new ligand derived by the condensation of isonicotinoylhydrazide and 3-ethoxysalicylaldehyde have been synthesized. Ligand was characterized on the basis of various spectroscopic techniques like IR, $1 \mathrm{H}$ and 13C NMR studies, elemental analysis. The compound was subjected to antimicrobial and anti-tubercular activity screening using serial broth dilution method and minimum inhibitory concentration (MIC) is determined. The ligand was evaluated for its antimicrobial activity against Gram-positive bacteria (Staphylococcus aureus ATCC 9144) and Gram-negative bacterium (Escherichia coli ATCC 11303). New compound synthesized showed good biological activity against tested bacteria. Furthermore, ligand shows high levels of activity against Mycobacterium tuberculosis (H37RV) in vitro.

Results: The elemental analysis, $1 \mathrm{H}$ and 13C NMR studies of ligand confirm the formation of title compound with the molecular formula C15H15N3O3. Ligand shows inhibition against mycobacterium at concentration $4 \mu \mathrm{g} / \mathrm{mL}$.

Conclusions: The schiff bases ligand was readily prepared for evaluation against $M$. tuberculosis in good yield. Compound show good activity in vitro.
\end{abstract}

Keywords: Schiff Base; isonicotinolhydrazone; Anti-tubercular; Antimicrobial

\section{Background}

Tuberculosis (TB) is a global emergency and is amongst the worldwide health threats today. TB remains the number one killer infectious disease affecting adults in developing countries [1]. Over the last two decades current control efforts are severely hampered due to Mycobacterium tuberculosis is a leading opportunistic infection in patients with the acquired immune deficiency syndrome and also due to the spread of multidrug-resistant strains (MDR-MTB) [2]. Inorganic medicinal chemistry is recently one of the most fields of research. The most significant part of this research has been directed to the development of drugs active against $M$. tuberculosis [3-5]. Hydrazones belonging to azomethine class of compounds have attracted the attention of many chemists owing to their wide spectrum of pharmacological activity profile with structural flexibility and ligating behavior. Hydrazones distinguished by the presence of two interlinked nitrogen atoms R1CN-NR2 are interesting, because they can function as antimicrobial, antitubercular and antitumor agents [6-8]. Having been used as the cornerstone of anti-tuberculosis therapy for more than half a century, much has been learned about the biochemistry and multifaceted modes of action of the frontline drug isoniazid. Indeed, with the enormous global burden of tuberculosis and the alarming rise in the number of clinical isolates displaying drug resistance or increased virulence [9-12], isonicotinic acid hydrazide has become the single most researched anti tubercular agent [13-15]. Isonicotinoylhydrazide (Isoniazid: INH) is one of the most potent anti-TB drugs, used to kill the M. tuberculosis. Isonicotinoylhydrazone derivatives containing heterocyclic moiety have found to exhibit better anti-tubercular activity $[16,17]$. We aimed to synthesize a potential ligand containing both, isonicotinoylhydrazide and 3-ethoxy-2-hydroxybenzilidine moieties, linked through azomethine group. Thus, the present investigation throw light on synthesis, characterization, antimicrobial and anti-tubercular activity of novel Schiff base ligand viz., N'-(3-ethoxy-2-hydroxybenzilidine) isonicotinohydrazide.

\section{Objectives}

We aimed to synthesize a potential ligand containing both, isonicotinoylhydrazide and 3-ethoxy-2-hydroxybenzilidine moieties, linked through azomethine group.

Copyright (C) 2015, Zahedan University of Medical Sciences. This is an open-access article distributed under the terms of the Creative Commons Attribution-NonCommercial 4.0 International License (http://creativecommons.org/licenses/by-nc/4.0/) which permits copy and redistribute the material just in noncommercial usages, provided the original work is properly cited. 
Thus, the present investigation throw light on synthesis, characterization, antimicrobial and anti-tubercular activity of novel Schiff base ligand viz., N'-(3-ethoxy-2-hydroxybenzilidine) isonicotinohydrazide.

\section{Materials and Methods}

Physical measurements: In this descriptive study, NMR spectra were recorded at ambient temperature with a Bruker Avance $500 \mathrm{MHz}$ spectrometer using DMSO as solvent, chemical shift values $(\delta)$ are given in ppm. Infrared spectra (4000 - $400 \mathrm{~cm}^{-1}$ ) were recorded as $\mathrm{KBr}$ discs with an IR Prestige-21 Shimadzu FT-IR spectrophotometer. Microanalyses $(\mathrm{C}, \mathrm{H}, \mathrm{N})$ of the ligands were carried out on a Leco CHNS elemental analyzer.

Synthesis of N'-(3-ethoxy-2-hydroxybenzilidine) isonicotinohydrazide ligand: 3-ethoxysalicylaldehyde (1.66 g, $0.01 \mathrm{~mol}$ ) was added to a solution of isonicotinohydrazide $(1.37 \mathrm{~g}, 0.01 \mathrm{~mol})$ in methanol $(30 \mathrm{~mL})$ and stirred for $3 \mathrm{~h}$. The pale yellowish solid separated was filtered, washed repeatedly with methanol, dried in air and recrystallized from ethanol (Figure 1). Yield: 93\%.

Antibacterial activity: Compound was prepared by dissolving $1 \mathrm{mg}$ of sample in $10 \mathrm{~mL}$ of $2 \%$ DMSO to give the concentration $100 \mu \mathrm{g} / \mathrm{mL}$. The standard solutions of Ceftazidime (antibacterial drug) and ceftriaxone (antifungal drug) were prepared in $2 \%$ DMSO to give concentration of $100 \mu \mathrm{g} / \mathrm{mL}$. Serial broth micro dilution was adopted as a reference method. Serial dilutions of test compound were made in broth, after which a standardized microorganism suspension was added. Quantities of test ligand were serially diluted to attain the final concentrations of 512, 256, 128, 64, 32, 16, 8, 4, 2, and $1 \mu \mathrm{g} / \mathrm{mL}$. One of the test tubes was kept as control. Each of the 10 test tubes was inoculated with a suspension of microorganism to be tested and incubated at $35^{\circ} \mathrm{C}$ for $18 \mathrm{~h}$. At the end of the incubation period, the tubes were visually examined for the turbidity. Cloudiness in the test tubes indicated that microorganism growth has not inhibited by the antibiotic contained in the medium at the test concentration. A serial dilution of test compound was made in broth, after which a standardized microorganism suspension was added. A quantity of test compound was serially diluted to attain the final concentrations of 512,256, $128,64,32,16,8,4,2$, and $1 \mu \mathrm{g} / \mathrm{mL}$. Test tubes were inoculated with suspension of microorganism $(1 \times 106 \mathrm{CFU} / \mathrm{mL})$ to be tested and incubated at $37^{\circ} \mathrm{C}$ for $24 \mathrm{~h}$. Cloudiness in the test tubes indicated that microorganism growth has not inhibited by the antibiotic contained in the medium at the test concentration.

Anti-tubercular activity: Test compound was evaluated for in vitro anti-mycobacterium activity. The MIC was determined and interpreted for M. tuberculosis H37Rv according to the procedure of the approved microdilution reference method of antimicrobial susceptibility testing [18]. Compound was taken at concentrations of 512, 256, 128, 64, 32, 16, 8, 4, 2, and $1 \mu \mathrm{g} / \mathrm{mL}$. M. tuberculosis H37Rv strain was used in Middle brook 7H-9 broth which was inoculated with standard as well as test compound and incubated at $37^{\circ} \mathrm{C}$ for 4 weeks. The bottles were inspected for growth twice a week for a period of 3 weeks. Reading was taken at the end of fourth week. The appearance with turbidity of $1 \times 106 \mathrm{CFU} / \mathrm{mL}$ was considered as bacterial growth and indicates resistance to the compound. The growth was confirmed by making a smear from each bottle. Test compound was compared to reference drugs isoniazid (MIC $=0.025 \mu \mathrm{g} / \mathrm{mL}$ ). The antimicrobial and anti-tubercular activity test was run in triplicate.

\section{Results}

The elemental analysis of ligand is in consistence with the molecular formula $\mathrm{C} 15 \mathrm{H} 15 \mathrm{~N} 3 \mathrm{O} 3$.

$1 \mathrm{H} \mathrm{NMR}\left(500 \mathrm{MHz}\right.$, [D6] DMSO, $\left.25^{\circ} \mathrm{C}\right): \delta=12.27(\mathrm{~s}, 1 \mathrm{H},-\mathrm{OH})$, $10.72(\mathrm{~s}, 1 \mathrm{H},-\mathrm{NH}), 8.69$ (s, 1 H, -CHN), $8.78[\mathrm{~d}, 3 \mathrm{~J}(\mathrm{H}, \mathrm{H})=5.55$ $\mathrm{Hz}, 2 \mathrm{H}, \mathrm{H}(11,12)], 7.85[\mathrm{~d}, 3 \mathrm{~J}(\mathrm{H}, \mathrm{H})=5.95 \mathrm{~Hz}, 2 \mathrm{H}, \mathrm{H}(10,13)]$, $7.17[\mathrm{dd}, 3 \mathrm{~J}(\mathrm{H}, \mathrm{H})=7.75 \mathrm{~Hz}, 4 \mathrm{~J}(\mathrm{H}, \mathrm{H})=0.95 \mathrm{~Hz}, 1 \mathrm{H}, \mathrm{H}(5)]$ $7.00[\mathrm{dd}, 3 \mathrm{~J}(\mathrm{H}, \mathrm{H})=7.90 \mathrm{~Hz}, 4 \mathrm{~J}(\mathrm{H}, \mathrm{H})=0.85 \mathrm{~Hz}, 1 \mathrm{H}, \mathrm{H}(3)]$, $6.82[\mathrm{t}, 3 \mathrm{~J}(\mathrm{H}, \mathrm{H})=7.90 \mathrm{~Hz}, 1 \mathrm{H}, \mathrm{H}(4)], 4.04[\mathrm{q}, 3 \mathrm{~J}(\mathrm{H}, \mathrm{H})=6.95$ $\mathrm{Hz}, 2 \mathrm{H},-\mathrm{OCH} 2], 1.33$ [t, 3J $(\mathrm{H}, \mathrm{H})=6.95 \mathrm{~Hz}, 3 \mathrm{H},-\mathrm{CH} 3] \mathrm{ppm}$.

13C NMR $(125 \mathrm{MHz}) \delta=161.2,150.3,149.1,147.5,147.1,139.9$, 121.4, 120.7, 119.1, 118.9, 115.4, 84.1,14.7 ppm.

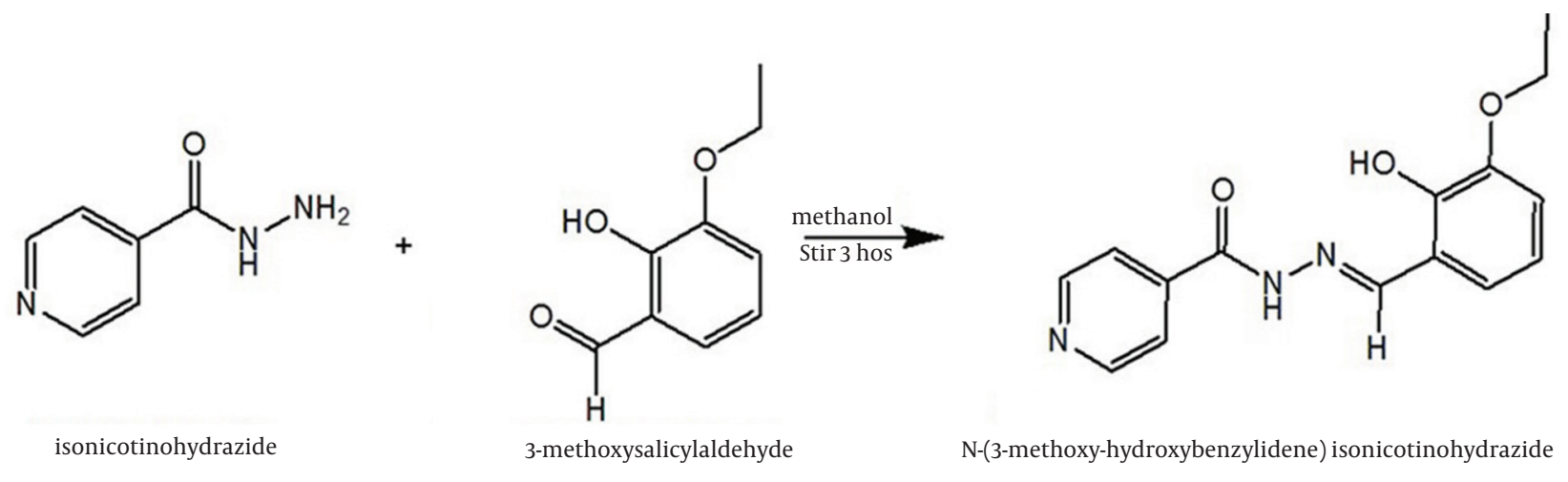

Figure 1. Synthetic Route for the Preparation of Ligand 
IR (KBr, cm-1); $3200(v \mathrm{~N}-\mathrm{H}) ; 1693(v \mathrm{C}=\mathrm{O}) ; 1602(v \mathrm{C}=\mathrm{N})$; 1564, 1466, ( $v \mathrm{C}=\mathrm{C}) ; 1257(v \mathrm{C}-\mathrm{O})$; $995(v \mathrm{~N}-\mathrm{N})$. Anal. Calc. for C15H15N3O3 (285.3) (\%): C, 63.15; H, 5.30; N, 14.73. Found (\%): C, 63.17; H, 5.23; N, 14.85 .

The ligand show higher activity against SA (MIC $8 \mu \mathrm{g}$ / $\mathrm{mL}$ ) and EC (MIC $4 \mu \mathrm{g} / \mathrm{mL}$ ) (Table 2).

The MIC of compound compared with isoniazid, standard anti tubercular drugs are summarized in Table 2 . Lignad show inhibition at concentration $4 \mu \mathrm{g} / \mathrm{mL}$.

\section{Discussion}

Ligand is soluble in solvents like DMF and DMSO but insoluble in common organic solvents. Anal. Calc. for C15H15N3O3: 285.3\%; C: 63.15\%; H: 5.30\%; N:14.73\%. Found, C: 63.17\%; H: 5.23\%; N: 14.85\%.

The IR band assignment of ligand is included in Table 1. IR spectrum of ligand is displayed in Figure 2. The coordination sites of ligand are determined using IR. The IR spectrum of the ligand exhibit two bands in the regions 3200 and $1693 \mathrm{~cm}^{-1}$ due to $v(\mathrm{NH})$ and $v(\mathrm{C}=\mathrm{O})$ stretches. A new band appearing in the $1257 \mathrm{~cm}^{-1}$ is assigned to the $v(\mathrm{C}-\mathrm{O})$ (enolic) mode. The band due to the imine group $v$ $(\mathrm{C}=\mathrm{N})$ mode of ligand at $1602 \mathrm{~cm}^{-1}$. In complex, the lactone carbonyl stretching has shifted to lower wave number by $32-75 \mathrm{~cm}^{-1}$ indicating its involvement in coordination [19]. Also, shift of (N-N) band to the higher frequency region can be taken as an additional evidence for the participation of azomethine group incoordination [20].

\begin{tabular}{lc}
\hline Table 1. Diagnostic IR Bands $\left(\mathrm{cm}^{-1}\right)$ of ACINH and its Complexes \\
\hline Functional Group & Characteristic Absorptions $\left(\mathbf{c m}^{-1}\right)$ \\
\hline$v(\mathbf{N H})$ & 3200 \\
$v(\mathbf{C}=\mathbf{O})$ & 1693 \\
$v(\mathbf{C}=\mathbf{N})$ & 1602 \\
$v(\mathbf{C}-\mathbf{O})$ & 1246,1157 \\
$v(\mathbf{N}-\mathbf{N})$ & 995 \\
\hline
\end{tabular}

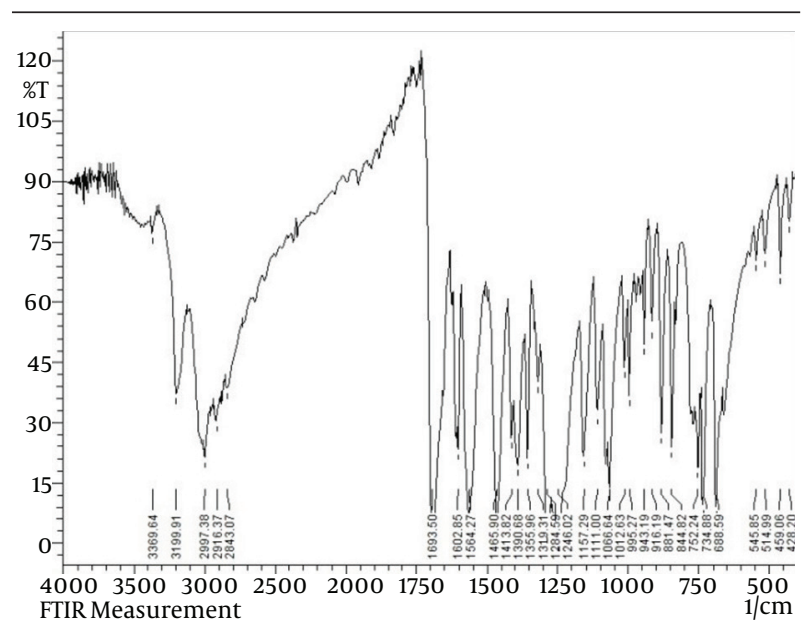

Figure 2. IR Spectrum of Ligand
Thus ligand functions as amonobasic tridentate ligand coordinating through lactone carbonyl oxygen, azomethine nitrogen and amide carbonyl oxygen via deprotonation.

Typical proton NMR spectra of the ligand was recorded at room temperature using DMSO as the solvent and the data was summarized in "Experimental" section. NMR of ligand has been analyzed in order to specify the coordination through lactone carbonyl oxygen and amide carbonyl oxygen. In the $1 \mathrm{H}$ NMR spectrum of ligand a signal at $12.27 \mathrm{ppm}$ is assignable to the $-\mathrm{OH}$ proton, while a signal at $10.72 \mathrm{ppm}$ is assigned to the -NH proton. Furthermore, azomethine proton is observed as a singlet at $8.69 \mathrm{ppm}$. Aromatic protons of the ligand appear well within the expected range. The aromatic protons of the ligand appeared at 6.81 - $9.79 \mathrm{ppm}$. Aromatic protons of the ligand appear well within the expected range. A quartet at $4.04 \mathrm{ppm}[3](\mathrm{H}, \mathrm{H})=6.95$ $\mathrm{Hz}$ ] is assigned to the - $\mathrm{OCH} 2$ protons, coupling with the $-\mathrm{CH} 3$ protons, while a triplet at $1.33 \mathrm{ppm}[3 \mathrm{~J}(\mathrm{H}, \mathrm{H})=6.95$ $\mathrm{Hz}$ ] is assigned to the - $\mathrm{CH} 3$ protons, coupling with the -OCH2 protons [19].

The prepared compound was screened for the inhibition of microbial growth under standard conditions, which may be utilized for demonstrating their antimicrobial efficacy using a serial broth microdilution method in 96 multi-cell micro liter plates [21]. Compound is tested at different concentrations and minimum inhibitory concentration (MIC) is determined. The antibacterial activity of synthesized compound is tested against bacteria like S. aureus (SA, ATCC 9144), E. coli (EC, ATCC 87261) and result is included in Table 2 . The antibacterial activity of synthesized compound is compared with standard antibacterial drug. The results are compared with standard antibacterial drug ciprofloxacin and ceftriaxone. The ligand show higher activity against SA (MIC $8 \mu \mathrm{g} / \mathrm{mL}$ ) and EC (MIC $4 \mu \mathrm{g} / \mathrm{mL}$ ) (Table 2).

As the ligand is a derivative of isoniazid, ligand was tested for anti-tubercular activity in order to compare with the activity of isoniazid (Table 2).

The anti-mycobacterium activity of the synthesized compound is assessed against M. tuberculosis H37RV at $512,256,128,64,32,16,8,4,2$, and $1 \mu \mathrm{g} / \mathrm{mL}$. The MIC of compound compared with isoniazid, standard anti tubercular drugs are summarized in Table 2. Ligand shows inhibition at concentration $4 \mu \mathrm{g} / \mathrm{mL}$. The Schiff bases ligand was readily prepared for evaluation against $M$. tuberculosis in good yield. Compound show strong level of activity in vitro $[22,23]$.

Therefore, the present study describes the preparation of N'-(3-ethoxy-2hydroxybenzilidine) isonicotinohydrazide. $1 \mathrm{H}$ and $13 \mathrm{C}$ NMR studies of ligand confirm the formation of title compound. Compound acts as monobasic, tridentate ligand. On the basis of this observation, structure is tentatively. In vitro anti-microbial and antitubercular activity of synthesized compound show good results enhancement of activity. 


\begin{tabular}{lccc}
\hline Table 2. In Vitro Antimicrobial Activity of the Compound and Standard Drug (MIC In $\mu \mathrm{g} / \mathrm{mL})$ & \\
\hline Compound & $\begin{array}{c}\text { Gram positive bacteria } \\
\text { (S. aurous ATCC 9144) }\end{array}$ & $\begin{array}{c}\text { Gram negative bacteria } \\
\text { (E. coli ATCC 11303) }\end{array}$ & $\begin{array}{c}\text { Mycobacterium tuberculosis } \\
\text { (M. tuberculosis H37RV) }\end{array}$ \\
\hline Ligand & 8 & 4 & 4 \\
Ceftriaxone & 0.010 & 0.015 & - \\
Ceftazidime & 0.015 & 0.020 & - \\
Isoniazid & - & - & 0.025 \\
\hline
\end{tabular}

\section{Acknowledgements}

We thank Infectious Diseases and Tropical Medicine Research Center, Zahedan university of medical sciences, for financial support. Appreciate the assistance of Ms. Saeede Mirfakhraei and Mr. Zakaria Bameri. (Project director: Elham Pahlavani, Code: 2453).

\section{Authors' Contributions}

All authors had equal role in design, work, statistical analysis and manuscript writing.

\section{Financial Disclosure}

The authors declare no conflict of interest.

\section{Funding/Support}

This study was financially supported by the Deputy of Research at Zahedan University of Medical Sciences.

\section{References}

1. Janin YL. Antituberculosis drugs: ten years of research. Bioorg Med Chem. 2007;15(7):2479-513.

2. Ibrahim M, Andries K, Lounis N, Chauffour A, Truffot-Pernot C, Jarlier V, et al. Synergistic activity of R207910 combined with pyrazinamide against murine tuberculosis. Antimicrob Agents Chemother. 2007;51(3):1011-5.

3. Bruijnincx PC, Sadler PJ. Controlling platinum, ruthenium and osmium reactivity for anticancer drug design. Adv Inorg Chem. 2009;61:1-62.

4. Humphrey J, Copsey M. Dalton Discussion 10: applications of metals in medicine and healthcare. Dalton Trans. 2007;(43):4883.

5. Ronconi L, Sadler PJ. Using coordination chemistry to design new medicines. Coordinat Chem Rev. 2007;251(13):1633-48.

6. Bottaria BRFA. Preliminary evaluation of the biological activities of zero generation hydrazones. Available from: http://shodhganga.inflibnet. ac.in/bitstream/10603/8747/12/12_chapter\%206.pdf.

7. Sridhar SK, Pandeya SN, Stables JP, Ramesh A. Anticonvulsant activity of hydrazones, Schiff and Mannich bases of isatin derivatives. Eur J Pharml Sci. 2002;16(3):129-32.

8. Oruc EE, Kocyigit-Kaymakcioglu B, Oral B, Altunbas-Toklu HZ, Kabasakal L, Rollas S. Synthesis of some novel azo derivatives of 3,5-dimethyl-1-(2-hydroxyethyl)pyrazole as potent analgesic agents. Arch Pharm (Weinheim). 2006;339(5):267-72.

9. Hearn MJ, Cynamon MH. Design and synthesis of antituberculars: preparation and evaluation against Mycobacterium tuberculosis of an isoniazid Schiff base. J Antimicrob Chemother. 2004;53(2):185-91.
10. Hearn MJ, Cynamon MH, Chen MF, Coppins R, Davis J, Joo-On Kang H, et al. Preparation and antitubercular activities in vitro and in vivo of novel Schiff bases of isoniazid. Eur J Med Chem. 2009;44(10):4169-78.

11. Boshoff HIM, Reed MB, Barry CE, Mizrahi V. DnaE2 polymerase contributes to in vivo survival and the emergence of drug resistance in Mycobacterium tuberculosis. Cell. 2003;113(2):183-93.

12. Fun HK, Chia TS, Bhat MA, Al-Omar MA, Abdel-Aziz HA. (E)-2-(2,3Dimethyl-anilino)-N'-(thio-phen-2-yl-methyl-idene)benzohydrazide. Acta Crystallogr Sect E Struct Rep Online. 2012;68(Pt 8):02524-5.

13. Bastian I, Portaels F. Multidrug-resistant tuberculosis. 1st ed. USA:: Springer; 2000. pp. 79-84.

14. 14. Wengenack NL, Rusnak F. Evidence for isoniazid-dependent free radical generation catalyzed by Mycobacterium tuberculosis KatG and the isoniazid-resistant mutant KatG (S315T). Biochemistry. 2001;40(30):8990-6.

15. Sharma RN, Sharma KP. Synthesis, characterization and biological activities of some new hypophosphorous adducts of acidhydrazones derived from 2-[(N-benzoyl)-2, 5-dichloroanilido] acetohydrazide. Asian J Chem. 2012;24(3):1271.

16. Sinha N, Jain S, Tilekar A, Upadhayaya RS, Kishore N, Jana GH, et al Synthesis of isonicotinic acid N'-arylidene-N-[2-oxo-2-(4-aryl-piperazin-1-yl)-ethyl]-hydrazides as antituberculosis agents. Bioorg Med Chem Lett. 2005;15(6):1573-6.

17. Kakimoto S, Yamamoto K. Studies on antitubercular compounds. $\mathrm{X}$. Condensation products of aldehydes and acid hydrazides of pyridine group. Pharm Bull.1956;4(1):4-6.

18. Laganas V, Alder J, Silverman JA. In vitro bactericidal activities of daptomycin against Staphylococcus aureus and Enterococcus faecalis are not mediated by inhibition of lipoteichoic acid biosynthesis. Antimicrob Agents Chemother. 2003;47(8):2682-4.

19. Jadhav SM, Shelke VA, Shankarwar SG, Munde AS, Chondhekar TK. Synthesis, spectral, thermal, potentiometric and antimicrobial studies of transition metal complexes of tridentate ligand. $J$ Saudi Chem Soc. 2014;18(1):27-34.

20. Nawar N, Hosny NM. Transition metal complexes of 2-acetylpyridine o-hydroxybenzoylhydrazone (APo-OHBH): their preparation, characterisation and antimicrobial activity. Chem Pharm Bull (Tokyo). 1999;47(7):944-9.

21. Machakanur S, Patil BR, Pathan AH, Naik GN, Ligade SG, Gudasi KB. Synthesis, antimicrobial and antimycobacterial evaluation of star shaped hydrazones derived from 1, 3, 5-triazine. Der Pharma Chemica. 2012;4(2):600-7.

22. Chohan $\mathrm{ZH}$, Praveen M. Synthesis, characterization, coordination and antibacterial properties of novel asymmetric 1,1?-disubstituted ferrocene-derived Schiff-base ligands and their $\mathrm{Co}(\mathrm{II}), \mathrm{Cu}(\mathrm{II}) \mathrm{Ni}(\mathrm{II})$ and $\mathrm{Zn}(\mathrm{II})$ complexes. Appl Organo Chem. 2001;15(7):617-25.

23. Murukan B, Mohanan K. Synthesis, characterization and antibacterial properties of some trivalent metal complexes with [(2-hydroxy-1-naphthaldehyde)-3-isatin]-bishydrazone. J Enzyme Inhib Med Chem. 2007;22(1):65-70. 